\title{
Cyclophosphamide identification in wipe test by GC-MS and solid phase extraction
}

\author{
Isarita Martins ${ }^{1 *}$, Henrique Vicente Della Rosa, Pietro Apostoli² \\ ${ }^{1}$ Department of Clinical and Toxicological Analysis, Faculty of Pharmaceutical Sciences, University of San Paolo, \\ ${ }^{2}$ Facoltà di Medicina e Chirurgia, Università degli Studi di Brescia
}

\section{*Correspondence:}

I. Martins

Departamento de Análises Clínicas e Toxicológicas

Faculdade de Ciências Farmacêuticas USP

Av. Prof. Lineu Prestes, 580 - Bloco 13B - Cidade Universitária

05508-900 - São Paulo - SP - Brasil
In this study cyclophosphamide was quantified after adapting a prior analytical method using gas chromatography-mass spectrometry after solid phase purification and derivatization with trifluoroacetic anhydride. The analyte was measured by analysis in wipe test from infusion bags, which may be contaminated by contact with the gloves used during preparation of the drugs. Surface of bag contaminated may be an important source of contamination for workers in the others chemoterapy handling areas, such as administration rooms. This drug, in fact, is one of the most frequently used alkylating antineoplastic agents for different types of tumors and it is furthermore classified as a human carcinogen by IARC. Ifosfamide was used as internal standard and the quantification was carried out by reference to calibration curves within a range from 1 to $100 \mathrm{ng} / \mathrm{mL}$. The limit of detection was 0.4 $n g / m L$. The values of the variation coefficient varied from 0.5 to $10 \%$ (intra-assay) and from 0 to $19 \%$ (interassay). Frozen reference wipe samples containing cyclophosphamide were analysed over one month and no significant loss was observed. The range obtained for bias assay was $83-116 \%$ and the recovery was $98.9 \%$. Cyclophosphamide was measured in 36 of 42 infusion bags collected from different hospitals with values ranging from 90 to $41874 \mathrm{ng}$ (median $=607.5 \mathrm{ng}$ ). The results, well related to those reported in the literature, suggest that this method can be used to identify cyclophosphamide from wipe samples and can be considered useful in exposure assessment to this drug.
Uniterms

- Cyclophosphamide

- Wipe test

- Exposure assessment

\section{INTRODUCTION}

The possibility of occupational hazards due to exposure to chemotherapeutic and antineoplastic agents was first recognized in the late 70s. At first, the observed effects were exclusively acute, as a consequence of dermal exposure and/or inhalation in accidents with aerosol formation or careless manipulation. The knowledge that 
chemotherapeutic agents might also be responsible for teratogenic effects and potentially carcinogenic, for the workers, is quite recent.

The overall evidence, combining the results from a variety of studies and bioassays, of carcinogenic risk to humans has been evaluated to be conclusive for at least ten cytostatic drugs, cyclophosphamide being one of them (Sorsa, Anderson, 1996).

As a genotoxic compound, it is not possible to establish a dose-effect relationship, although exposure is considered inappropriate even in small doses.

At the occupational level, the main contamination route is dermal contact, which may occur by prolonged contact with either contaminated surfaces or instruments (Sessink, Bos, 1999). Glove analysis might be helpful in the evaluation of dermal exposure of workers to antineoplastic drugs. Another possible source of contamination is the inhalation of aerosols dispersed throughout the working place (Alessio et al., 1996; Sorsa, Anderson, 1999; Sessink, Bos, 1999).

The opportunities for exposure are easily identified. During the preparation procedure of some drugs, some steps are particularly hazardous, such as the opening of the glass vial, removal of the needle from the vial (which may produce aerosol formation), bleeding of air from the syringe, transfer of the drug from one vial to another by means of a syringe or a needle, and inappropriate discarding of a partially used vial. In the administration procedure, exposure may occur during the bleeding from the syringe, by aerosol formation or by direct skin contact. In routine hospital practice, the contact with biological material or undergarments from patients treated with these drugs represents another possible source of exposure (Sessink, 1994; Sessink, Bos, 1999).

Some national and international agencies concerned with labor safety have published documents providing precise directives aimed at reducing exposure risks during manipulation of antineoplastic drugs. Commonly, these guidelines ask for periodical exposure evaluation, use of collective and individual protective devices, and establishment of sanitary surveillance and informative programs, in order to guarantee the lowest possible levels of exposure (Minoia, Perbellini, 2000).

Workers at risk are usually exposed to more than one antineoplastic chemotherapeutic agent; for this reason, it is necessary to determine which substances might be considered indicators of such exposure. These pharmacological drugs can be assessed in environmental and biological matrices according to the following hierarchic sequence: a) surface detection, called wipe test; b) detection in biological material and c) environmental detection (Alessio et al., 1996). For instance, surface analysis of a working space often gives positive results while air samples collected from the same space might not show any contamination (Apostoli et al., 1996).

This work seeks to determine the concentration of cyclophosphamide (CP) in wipe test samples collected from the surfaces of infusion bags, using gas chromatography coupled to mass spectrometry, after solid phase extraction. Infusion bags may become contaminated by contact with gloves donned during the preparation of chemotherapeutic drugs and may constitute an important source of contamination for workers who administer such drugs.

\section{MATERIAL AND METHODS}

\section{Study design}

$\mathrm{CP}$ was chosen as tracing substance, since it is one of the most utilized antineoplastic drugs and also one of the most toxic ones (class 1 of IARC).

Forty-two infusion bags were collected from four different hospital centers. In order to screen for contamination, wipe test were collected from the outer surfaces of the bags. Samples were taken during the first and third weeks of $\mathrm{CP}$ usage, providing that at least $6 \mathrm{~g}$ of $\mathrm{CP}$ were used on the collection days. During the investigation, questionnaires about the characteristics of the work were answered.

For the wipe test sampling procedure, previously delimited surfaces were washed with $20 \mathrm{~mL}$ of $0.03 \mathrm{~mol}$ $\mathrm{L}^{-1} \mathrm{NaOH}$ and subsequently wiped with two sheets of absorbent paper. The absorbent paper was then placed in an appropriate recipient and sent to the laboratory packed in dry ice, being kept at $-20^{\circ} \mathrm{C}$ until analysis.

\section{Chemicals}

CP (ACRÓS-USA; purity $>97 \%$ ) and ifosfamide (Holoxan ${ }^{\circledR}$ - ASTA- PHARMA- Italy; purity $>97 \%$ ); trifluoroacetic anhydride (SIGMA- USA; purity $>99 \%$ ). The other chemicals were of the highest purity obtainable.

\section{Analytical conditions}

The analyses were performed with a $6890 \mathrm{GC}$ coupled to a 5972-A MS (gas chromatography-mass spectrometry-Hewlett Packard ${ }^{\circledR}$ ), both controlled by a Vectra XM series 3 5/9- Hewlett Packard ${ }^{\circledR}$ personal computer. The analytical column used was a HP5-MS, 30 $\mathrm{m}, 0.25 \mathrm{~mm}$ internal diameter and $0.25 \mu \mathrm{m}$ film thickness- 
Hewlett Packard ${ }^{\circledR}$ connected with a deactivated fused silica retention gap (HP Retention Gap $5 \mathrm{~m}, 0.53 \mathrm{~mm}$ internal diameter- Hewlett Packard $\left.{ }^{\circledR}\right) .1 \mu \mathrm{L}$ of the cleaned sample was injected in the on-column mode; the initial injector temperature was $80^{\circ} \mathrm{C}$. After $1 \mathrm{~min}$, the injector temperature was increased at $75{ }^{\circ} \mathrm{C} / \mathrm{min}$ to $300{ }^{\circ} \mathrm{C}$, remaining constant. The initial oven temperature was $70{ }^{\circ} \mathrm{C}$. After $1 \mathrm{~min}$, the temperature was increased at $15{ }^{\circ} \mathrm{C} / \mathrm{min}$ to $250{ }^{\circ} \mathrm{C}$, where it remaining constant for $3 \mathrm{~min}$ and, after this, was increased at $30^{\circ} \mathrm{C} / \mathrm{min}$ to $300{ }^{\circ} \mathrm{C}$, and held constant for $5 \mathrm{~min}$. Helium (He) was used as carrier gas (column inlet pressure $82 \mathrm{kPa}$ ). The interface temperature was $310^{\circ} \mathrm{C}$.

Initially, $\mathrm{CP}$ and the internal standard identification was carried out in the SCAN mode, with full spectra (50 to $350 \mathrm{~m} / \mathrm{z}$ ) from the tenth to the fifteenth minute of the chromatographic run. From the full spectra, ions fragments 307 and 309 were selected for analysis in the SIM mode. Finally, the analyte was identified by the presence of ions 307 and 309 and by the relative retention time of $\mathrm{N}$-trifluoroacetylated $\mathrm{CP} /$ ifosfamide.

Quantification was performed on the selected ion fragment 307 and the peak area ratio of $N$ trifluoroacetylated derivatives $\mathrm{CP} /$ ifosfamide was calculated. By reference was carried out a calibration cur$\mathrm{ve}$, ranging from 1 to $100 \mathrm{ng} / \mathrm{mL}$ of $\mathrm{CP}$, treated as samples and injected before each set of samples.

\section{Sample treatment}

The following procedure is a modification of Sessink et al. (1992). The original technique utilized liquid-liquid extraction, whereas the present work used solid phase extraction with a modified form of a diatomaceous earth packed into polypropylene cartridge.

\section{Extraction procedure}

Thirty milliliters of $0.03 \mathrm{~mol} \mathrm{~L}^{-1} \mathrm{NaOH}$ were added to the sample flask, together with $20 \mathrm{~mL}$ of aqueous $\mathrm{NaOH}$ solution previously collected. After sonication for $90 \mathrm{~min}$ and shaking for $10 \mathrm{~min}$, the sample was centrifuged at $3000 \mathrm{rpm}$ for $10 \mathrm{~min}$. To the supernatant (1 $\mathrm{mL}), 1 \mathrm{~mL}$ of TRIS buffer $(0.2 \mathrm{~mol} / \mathrm{L} ; \mathrm{pH} 4.5)$ and $20 \mu \mathrm{L}$ of internal standard (ifosfamide $5 \mathrm{mg} / \mathrm{mL}$ ) were added. One milliliter of this mixture was placed on the extraction column. After $5 \mathrm{~min}$, it was eluted twice with $5 \mathrm{~mL}$ of ethyl acetate and the extract was dried in an evaporator centrifuge under vacuum. Ethyl acetate $(50 \mu \mathrm{L})$ and trifluoroacetic anhydride $(50 \mu \mathrm{L})$ were added and mixed. The vial was closed for derivatization at $70{ }^{\circ} \mathrm{C}$ for $20 \mathrm{~min}$. After cooling at room temperature, the sample was dried with the evaporator centrifuge under vacuum, and $50 \mu \mathrm{L}$ of toluene were then added. The sample was then sonicated for 3 min and stored at $-20{ }^{\circ} \mathrm{C}$ until analysis.

\section{Validation of the method}

The validation of the method was performed by establishing limits of detection and quantification, linearity, accuracy, recovery, precision and stability, acording to FDA, 1996 and FDA, 1998.

\section{Statistical analysis}

A Kruskall-Wallis test was performed to assess significant differences between the levels of CP in different hospital centers as mentioned above. For the statistical calculations the InStat software package was used.

\section{RESULTS AND DISCUSSION}

The analytical conditions were selected for measurement of CP surface contamination because they provided a suitable method. CP determination in environmental matrices, such as a wipe test collected from the surface of the infusion bags, was performed according to the method proposed by Sessink et al., in 1992, that employed gas chromatography coupled to mass spectrometry to identificate the analyte.

Most of the several methods for CP determination in wipe samples employ extraction procedures using liquidliquid extraction with ethyl acetate (Sessink et al., 1992; Minoia et al., 1998; Connor et al., 1999; Schmaus et al., 2002). In the present work, the sample was extracted with a solid phase, using a diatomaceous earth column. The use of this column provided a clean extract (Figure 1). It furthermore reduces the occupational exposure of the analyst to the solvent ethyl acetate, an important characteristic when a method is in routine use. Evelo et al. (1986) utilized an amberlite XAD-2 column to substitute the liquid-liquid extraction of CP from complete $24 \mathrm{~h}$ urine, concentrating on XAD- 2 of only $10 \%$ of the urine. In this case, the method is more suitable as an exposure test for routine purposes.

The mass spectra of $N$-trifluoroacetylated $\mathrm{CP}$ and ifosfamide, obtained in SCAN mode, was in agreement with Sessink et al. (1993). Two ions were chosen for CP identification: 307 , the most abundant in the derivatized molecule and more frequently discussed in the literature (Sessink et al., 1992; Sessink et al., 1993; Connor et al., 1999); and 309, previously utilized by Evelo et al. (1986) 
and Schmaus et al. (2002). In the present study, the ion 309 had a response three times lower than ion 307 . The use of both ions led to some loss of instrumental sensitivity, but it conferred increased certainty in identification.

The relative retention time obtained by this procedure (1.06) was another parameter used to identify the substance. Peaks of $N$-trifluoroacetylated $\mathrm{CP}$ and ifosfamide were completely separated, without interference within their respective retention times, as shown in Figure 1. Our study is characterized by a relatively simple and fast chromatographic run, permitting the analysis of a considerable number of samples within a work day.

The validation results (Table I) were considered satisfactory because they are comparable to previous studies. However, the interassay precision coefficient exceed $15 \%$, when analysed at the limit of quatífication. Connor et al. (1999), using gas chromatography coupled to a tandem mass spectrometer, obtained lower coefficients.

TABLE I - Confidence parameters of the proposed method for cyclophosphamide determination in wipe test by GCMS and previous solid phase extraction

\begin{tabular}{ll}
\hline Parameter & Result \\
\hline limit of detection (LOD) & $0.4 \mathrm{ng} / \mathrm{ml}$ \\
limit of quantification (LOQ) & $1.0 \mathrm{ng} / \mathrm{ml}$ \\
dynamic range & $1-100 \mathrm{ng} / \mathrm{ml}$ \\
correlation coefficient & 0.9993 \\
accuracy (bias) & $83-116 \%$ \\
recovery & $98.9 \%$ \\
precision (range of coefficient & intra-assay: $0.5-10 \%$ \\
of variation) & interassay: $0-19 \%$ \\
stability & 30 days at $-20^{\circ} \mathrm{C}$ \\
\hline
\end{tabular}

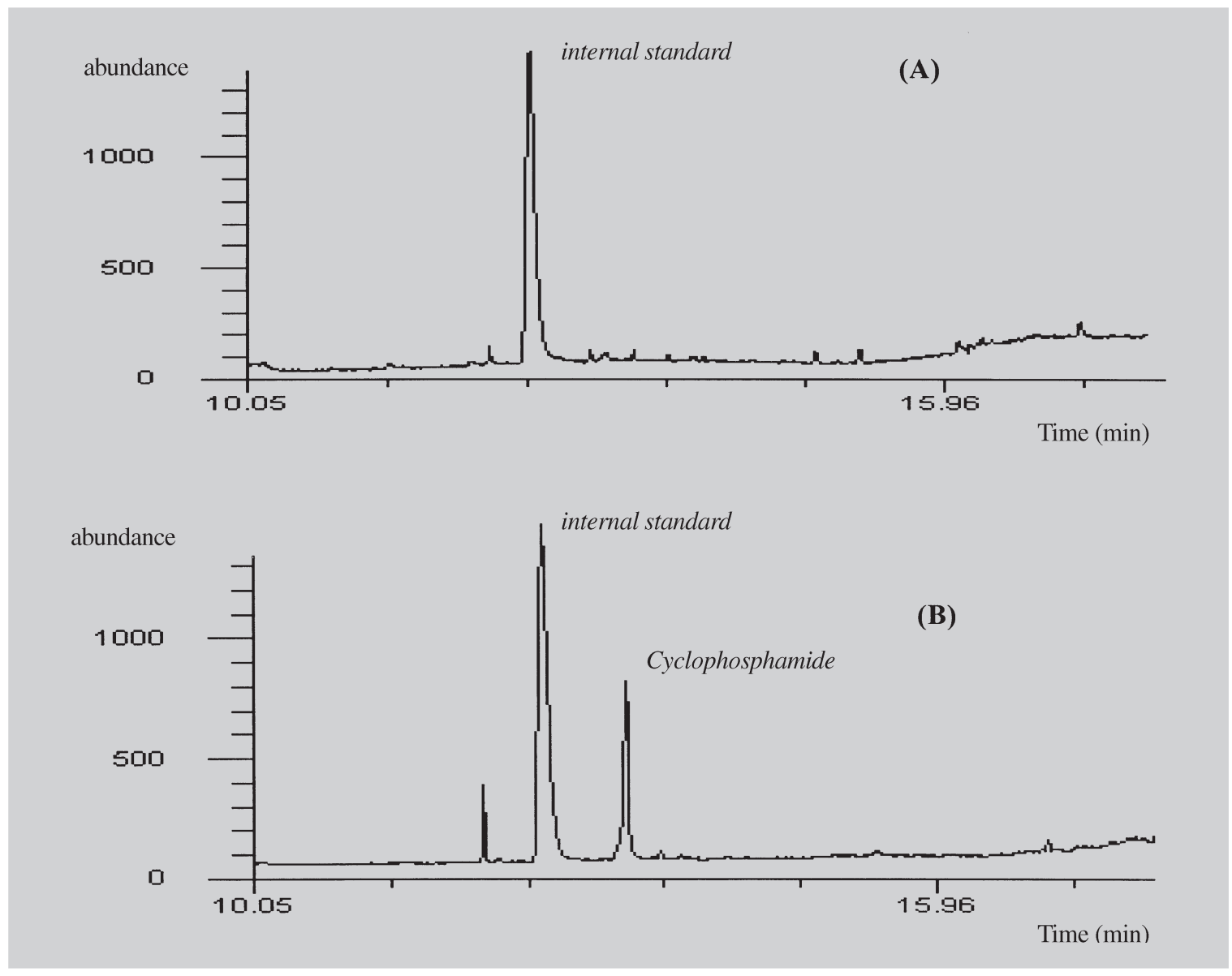

FIGURE 1 - Analytical chromatogram of infusion bags from analysis by CG-MS (SIM mode: ion 307) after purification by a diatomaceous column: (A) cyclophosphamide concentration was non quantified; (B) sample with $640 \mathrm{ng}$ of cyclophosphamide. The retention times: internal standard=12.5 min and cyclophosphamide $=13.3 \mathrm{~min}$. 
The method accuracy varied from $116 \%$ for wipe test with a nominal concentration of $30 \mathrm{ng} / \mathrm{mL}$ of CP, to $83 \%$ for $100 \mathrm{ng} / \mathrm{mL}$ samples. Minoia et al. (1998) obtained an accuracy ranging from 98 to $109 \%$ for CP analysis in pads, analyzed by liquid chromatography coupled to a tandem mass spectrometer.

Our method resulted in a recovery of $98.9 \%$, which is comparable to other work. Pyy et al. (1988) obtained $97 \%$ recovery in CP analysis in air samples. Minoia et al. (1998) obtained mean values above $85 \%$, McDevitt et al. (1993) reported a similar recovery and Schmaus et al. (2002) obtained a recovery between 60 and 100\%. In these studies a liquid-liquid extraction was used.

The described method produced a linear curve in the concentration range of $1-100 \mathrm{ng} / \mathrm{mL}$, with a correlation coefficient of 0.9982 . We were able to detect $\mathrm{CP}$ within this range in the majority of the samples $(85.7 \%)$. A similar correlation coefficient was found by Sessink et al. (1993), in urinary CP analysis.

The analyte remains stable for one month, if stored at $-20{ }^{\circ} \mathrm{C}$. The $\mathrm{CP}$ concentration decreases up to two standard deviation values during this period. Pyy et al. (1988) observed that in 8 days there is a decrease of $15 \%$ of the CP concentration on filters, for air sampling, and of $25 \%$ in the water extracts. Sessink et al. (1992) did not observe significant $\mathrm{CP}$ losses during a three months period for urine analysis, with concentrations of $11.7 \mathrm{ng} / \mathrm{mL}$. The disagreement between our results and those obtained by Sessink et al. (1992) could be explained by analysis of different types of samples.

Table II shows median concentrations of $\mathrm{CP}$ and the respective intervals found in the analyzed infusion bags. $\mathrm{CP}$ levels ranged from $<1.0 \mathrm{ng} / \mathrm{mL}$ to $41874 \mathrm{ng}$ / infusion
TABLE II - Average concentrations of cyclophosphamide (ng) in infusion bags samples from four different hospital centers

\begin{tabular}{ccc}
\hline $\begin{array}{c}\text { Hospital } \\
\text { center }\end{array}$ & $\begin{array}{c}\text { Average concentration } \\
\text { of cyclophosphamide } \\
\text { (ng/ infusion bag) }\end{array}$ & $\begin{array}{c}\text { Range of } \\
\text { concentration } \\
\text { (ng/infusion bag) }\end{array}$ \\
\hline $\mathbf{1}$ & 441 & $115.0-1077.2$ \\
$\mathbf{2}$ & 616 & $320.0-21975$ \\
$\mathbf{3}$ & 155 & $\mathrm{NQ}^{(1)}-850.0$ \\
$\mathbf{4}$ & 911 & $\mathrm{NQ}^{(1)}-41874$ \\
\hline
\end{tabular}

Note: (1) NQ: non quantified- below $1.0 \mathrm{ng} / \mathrm{mL}$

bag. Sessink et al. (1992) found $2100 \mathrm{ng}$ of CP in this kind of analysis.

Of the 42 analyzed samples, 6 presented CP concentrations below the quantification level $(1.0 \mathrm{ng} / \mathrm{mL})$. The other 36 samples revealed CP contamination of infusion bags in some level from all of the four hospital centers. Although center 4 showed the highest individual levels of contamination (Figure 2), it also presented the highest number of samples with no detectable contamination. As the $p$ value obtained was 0.1516 (Kruskall-Wallis test), the statistical difference was considered not significant, between the four hospital centers.

The results obtained in the present study reinforce those reported in the specialized literature and show CP contamination on several surfaces of infusion bags in the chemotherapy handling areas. Such contamination could result in ingestion and/or dermal absorption of CP. These positive samples suggest that the drug handling procedures are not adequate. Infusion bags may be

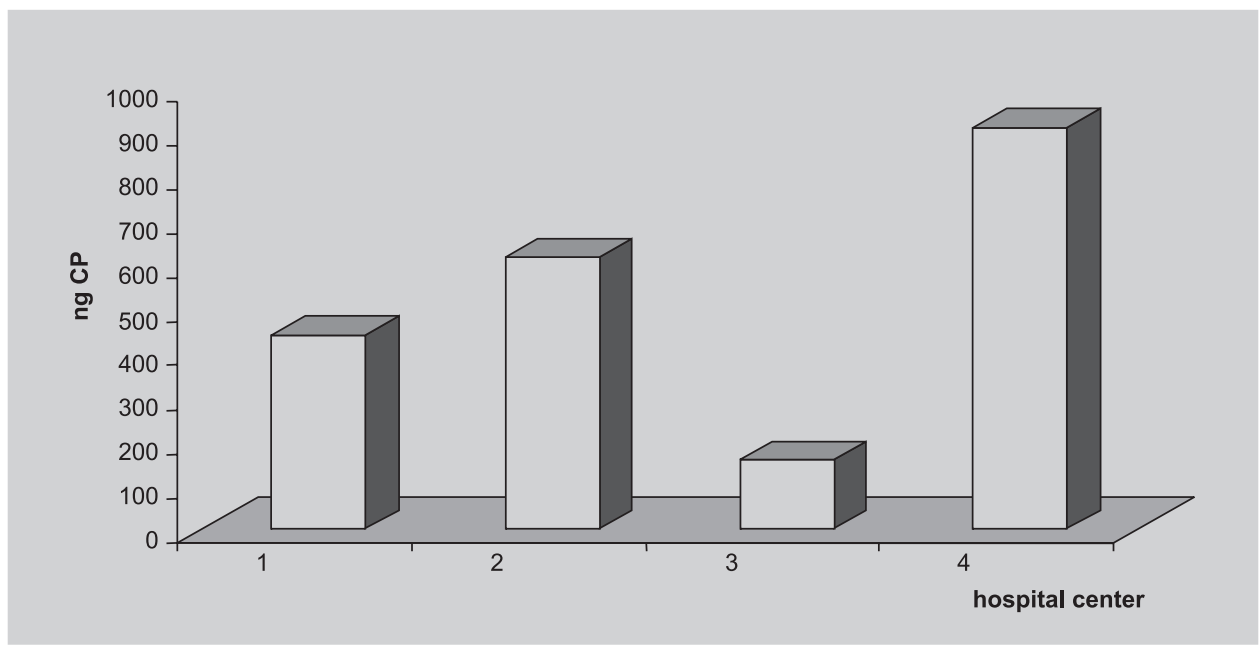

FIGURE 2 - Average concentration of cyclophosphamide (CP), in ng, from infusion bags samples collected in four hospital centers (Kruskall-Wallis test: $p>0.05$ ). 
contaminated by gloves utilized by hospital workers. In addition, contamination of surfaces also increases the risk of exposure to others in the areas.

Sessink et al. (1997) suggest that cyclophosphamide excretion can be lower when we know the exact relationship between sources of exposure, distribution of sources and absorption of this agent.

The present methodology can be used to identify CP in wipe test samples. Furthermore, our results suggest that infusion bags could be valuable monitoring targets for assessment of dermal exposure during preparation and administration of antineoplastic drugs.

\section{ACKNOWLEDGEMENTS}

This work was conducted with doctoral fellowship sponsored by CAPES-Brazil.

\section{RESUMO}

\section{Identificação de ciclofosfamida em wipe teste por CG-EM com prévia extração em fase sólida}

A ciclofosfamida é uma agente alquilante freqüentemente utilizado na prática clínica para diferentes tipos de tumores e, é classificado como carcinógeno para humanos pelo IARC. Neste estudo, o fármaco foi quantificado, após adaptação de um método analítico, utilizando a cromatografia gasosa acoplada à espectrometria de massa com prévia extração em fase sólida e derivação com anidrido trifluoroacético. Foram utilizadas como amostras, bolsas de infusão as quais podem estar contaminadas pelo contato com luvas usadas durante o preparo dos medicamentos, constituindo importante fonte de contaminação para trabalhadores em outras áreas da quimioterapia, tais como a sala de administração do medicamento ao paciente. A ifosfamida foi utilizada como padrão interno e a quantificação foi realizada com auxílio de curva de calibração, em um intervalo dinâmico de 1 a $100 \mathrm{ng} / \mathrm{mL}$. O limite de detecção do método foi $0,4 \mathrm{ng} / \mathrm{mL}$. Os coeficientes de variação obtidos, no ensaio de precisão, foram de 0,5 a 10\% (intra-ensaio) e de 0 a 19\% (interensaio). O analito permaneceu estável na matriz após um mês de congelamento das amostras, sem perdas significativas. No teste de exatidão os resultados variaram de 83 a $116 \%$ e a recuperação do método foi de 98,9\%. A ciclofosfamida foi determinada em 36 das 42 bolsas coletadas em quatro diferentes hospitais, com valores que variaram de 90 a $41874 \mathrm{ng}$ (mediana $=607,5 \mathrm{ng}$ ). Os resultados, bem correlacionados com os anteriormente relatados na literatura, sugerem que este método pode ser usado na iden- tificação da ciclofosfamida e pode ser considerado importante ferramenta na monitorização da exposição aos fármacos antineoplásicos.

Unitermos: ciclofosfamida, wipe teste; avaliação da exposição

\section{REFERENCES}

ALESSIO, L.; APOSTOLI, P.; DRAICCHIO, F.; FORNI, A.; LUCCHINI, R.; MERLER, E.; PALAZZO, S.; SCARSELLI, R.; SOSSAI, D. Prevenzione dei rischi da esposizione professionale a chemioterapici antiblastici. Documento de consenso. Med. Lav., Milano, v.87, n.3, p.194-200, 1996.

APOSTOLI, P.; CLONFERO, E.; COTTICA, D.; BERGAMASCHI, A.; MOCCALDI, R.; DRAICCHIO, F.; TRANFO, G.; SANNOLO, N.; SOSSAI, D. Criteri e metodi per lo studio dell'esposizione occupzionale a chemioterapici antiblastici. Med. Lav., Milano, v.87, n.3, p.230-254, 1996.

CONNOR, T. H.; ANDERSON, R. W.; SESSINK, P. J.; BROADFIELD, L.; POWER, L. A. Surface contamination with antineoplastic agents in six cancer treatment centers in Canada and United States. Am. J. Health Syst. Pharm., Wisconsin, v.56, p.1427-1432, 1999.

EVELO, C. T. A.; BOS, R. P.; PETERS, J. G. P.; HENDERSON, P. TH. Urinary cyclophosphamide assay as a method for biological monitoring of occupational exposure to cyclophosphamide. Int. Arch. Occup. Environ. Health, Berlin, v.58, p.151-155, 1986.

FOOD AND DRUG ADMINISTRATION. Center for Drug Evaluation and Research. $Q 2 B$ validation of analytical procedures: methodology: guidance for industry. Rockville: FDA, 1996. p. 1-10.

FOOD AND DRUG ADMINISTRATION. Center for Drug Evaluation and Research. Bioanalytical methods validation for human studies: guidance for industry. Rockville: FDA, 1998. p. 1-13.

McDEVITT, J. J.; LEES, P. S. J.; McDIARMID, M. A. Exposure of hospital pharmacists and nurses to antineoplastic agents. J. Occup. Med., Chicago, v.35, n.1, p.57-60, 1993. 
MINOIA, C.; TURCI, R.; SOTTANI, C.; SCHIAVI, A.; PERBELLINI, L.; ANGELERI, S.; DRAICCHIO, F.; APOSTOLI, P. Application of high-performance liquid chromatography/tandem mass spectrometry in the environmental and biological monitoring of health care personnel occupationally exposed to cyclophosphamide and ifosfamide. Rapid Commun. Mass Spectrom., London, v.12, p.1485-1493, 1998.

MINOIA, C.; PERBELLINI, L. Monitoraggio ambientale e biologico dell'esposizione professionale a xenobiotici: chemoterapici antiblastici. Milano: Morgan, 2000. v.3, $265 \mathrm{p}$.

PYY, L.; SORSA, M.; HAKALA, E. Ambient monitoring of cyclophosphamide in manufacture and hospitals. Am. Ind. Hyg. Assoc. J., Guilford, v.49, n.6, p.314-317, 1988.

SCHMAUS. G.; SCHIERL, R.; FUNCK, S. Monitoring surface contamination by antineoplastic drugs using gas chromatography-mass spectrometry and voltammetry. Am. Soc. Health Syst. Pharm., Bethesda, v.59, n.10, p.956-961, 2002.

SESSINK, P. J. M.; BOER, K. A.; SCHEEFHALS, A. P. H.; ANZION, R. B. M.; BOS, R. P. Occupational exposure to antineoplastic agents at several departments in a hospital. Int. Arch. Occup. Environ. Health, Berlin, v.64, p.105-112, 1992.
SESSINK, P. J. M.; SCHOLTES, M. M.; ANZION, R. B. M.; BOS, R. P. Determination of cyclophosphamide in urine by gas chromatography-mass spectrometry. $J$. Chromatogr., Amsterdam, v.616, p.333-337, 1993.

SESSINK, P. J. M.; Van de KERKHOLF, M. C. A. Environmental contamination and assessment of exposure to antineoplastic agents by determination of cyclophosphamide in urine of exposed pharmacy technicians: is skin absorption an important exposure route? Arch. Environ. Health, Chicago, v.49, p.165-169, 1994.

SESSINK, P. J. M.; WITTENHORST, B. C. J.; ANZION, R. B. M.; BOS, R. P. Exposure of pharmacy technicians to antineoplastic agents: reevaluation after additional protective measures. Arch. Environ. Health, Chicago, v.52, n.3, p. 240-244, 1997.

SESSINK, P. J. M.; BOS, R. P. Drugs hazardous to healthcare workers. Evaluation of methods for monitoring occupational exposure to cytostatic drugs. Drug Safety, Auckland, v.20, n.4, p.347-359, 1999.

SORSA, M.; ANDERSON, D. Monitoring of occupational exposure to cytostatic anticancer agents. Mutat. Res., Amsterdam, v.355, p.253-261, 1996.

Recebido para publicação em 30 de abril de 2003. 